\title{
La Filosofía de Guyau
}

\section{SUS ESTUDIOS SOBRE EPICURO, EPICTETO}

\section{Y LA MORAL INGLESA CONTEMPORANEA}

NTES de entrar Guyau a exponer sus propias doctrinas éticas se defuvo en el estudio crítico de las ideas utilitarias desde Epicuro hasta nuestros días. Dedicó asimismo su atención al examen de las enseñanzas de Epicteto.

Con marcada delectación recorre y examina Guyau la obra de Epícuro (1) y resulta también un deleite para el lector conocer al maestro del placer a través de semejante guía.

iCómo se ha adulterado en el lenguaje corriente el sentido de los términos -epicureísmo, sepicúreos, sbusca del placers! ¡Cómo se ha desfigurado por ciertas escuelas la personalidad de Epicurol Este supuesto monstruo que hiciera consistir el bien en el placer era en realidad un santo. Por su sobriedad, austeridad y renuncia de lo superfluo podía competir con el más adusto de los estoicos. Para su felicidad le bastaba, como él decia, pan y agua.

Pero su palabra no resonó en vano en la fronda de su jardín. Epicuro gozó de una popularidad enorme. A la escuela que abriera en Atenas a fines del siglo IV A. J. C. acudieron discípulos de todos los ámbitos del mundo greco-romano. Hasta de Egipto iba gente a escucharlo y, según Cicerón, el mismo mundo bárbaro no se sustrajo a su influencia. En Roma sus ideas socavaron definitivamente los cimientos de la vieja religión de Lacio. Séneca le critica, pero al mismo tiempo se nutre de él, lo cita y lo admira. Marco Aurelio. sin abandonar su noble credo estoico, vuelve los ojos a Epicuro, se exhorta a imitarlo y funda en Atenas una cátedra de epicureísmo.

(1) La Morale d'Epicure. 
Al frente del cristianismo triunfante adolecian las ideas de Epicuro de una vacuidad irremediable, de algo incompleto para las masas y las almas sedientas de más allá. El cristianismo abría ante las tribulaciones de la vida las perspectivas de una gloria eterna. El epicureísmo afirmaba con serenidad heroica la extinción total de la existencia humana. De aquí la decadencia de la filosolía de Epicuro hasta principios de los tiempos modernos. Cuando despúes del Renacimiento empezó a abrirse brecha en el dogma cristiano. el epicureísmo cobró nueva vida. Con Hobbes y Gassendi volvió a la palestra en el siglo XVII para llegar. sobre todo en Inglaterra y Francia floreciente de vigor hasta nuestros dias.

Veamos las ideas esenciales de Epicuro.

Siguiendo un camino inverso al de Platón. que buscaba la verdad antes de inferir cual sería el bien. Epicuro trata de establecer en qué consiste el bien antes de dirigir su atención a la busca de la verdad en sí. Para nuestro filósolo el soberano bien reside en el placer. Ya veremos a qué queda reducido en definitiva este placer.

Todos los seres animales persiguen el placer y la misma razón humana se encuentra en la imposibilidad de concebir un bien abstracto. despojado de todo elemento sensible. Hablando en términos parecidos a los de los estoicos, dice Epicuro que la inteligencia del hombre debe plegarse a la naturaleza y no tratar de doblegarla. Siguiéndola ha de buscar el placer.

La virtud, la ciencia y la sabiduría no constituyen para los epicúreos de ninguna manera fin es en si; no son más que medios. Se ve que el epicureísmo es anti-intelectualista. El pragmatismo norte-americano nos resultaría así un eco del verbo epicúreo en que en lugar del placer se señalaría la acción como el fin propio del hombre. Eco en apariencia más viril que aquella voz de la antigüedad. pero no en realidad porque Epicuro fué, por la fuerza de las cosas, más austero que cualquier filósolo de nuestros días.

Aristipo habia señalado igualmente como objetivo de la vida el placer; pero no habia sabido pasar más allá del placer momentáneo. En el goce del instante fugitivo encerraba toda su filosolía.

Epicuro sobrepasa con mucho a Aristipo. Señala aquél en verdad como placeres fundamentales los de los sentidos: del gusto, de la vista, del oído y de Venus. Ahondando más llega a dar entre esos el primer lugar a los que se encuentran en la raíz de la vida a los placeres del vientre. Pero luego entra en una fina distinción cuyas consecuencias van muy lejos. Observa que hay muchos placeres que luego se cambian en dolor y que no es raro tampoco que haya dolores que traigan en sus adustos pliegues el placer. De aqui la necesidad de que el espíritu se adelante al momento transitorio y mire al porvenir. Queda con esto introducida la idea del tiempo y la doctrina del mero placer convertida en la de la utilidad. El sabio debe buscar no el goce lugaz sino la felicidad durable. Sabio no quiere decir en este caso ni erudito ni docto. Sabio es el que po- 
see el arte de vivir, don cuyos beneficios el filósolo debe aspirar a poner al alcance de todos. Para conseguirlo hay que despojar a ese engañoso concepto de felicidad de cuanto tiene de superfluo, de todo elemento difícil de procurarse. como las riquezas, el lujo, los honores, el poder. Por este camino se van apar. tando más y más los ingredientes materiales de la concepción del placer, se va dejando más espacio a la libertad en la conquista de la felicidad, y, de esta suerte se va a ensanchar también el lugar que le corresponde a la moralidad.

Distingue Epicuro en los deseos tres categorias: los naturales y necesarios. los naturales y no necesarios y los que no son ni naturales ni necesarios y brotan como engendros de una vana opinión. Pertenecen a la primera clase los que tienden a aplacar un dolor como el deseo de la bebida para la sed; a la segunda los que buscan solamente la variación de la voluptuosidad, pero no aplacan un dolor, como el de los guisos delicados; y a la tercera los que van tras la satisfacción de una pura vanidad como es la de suspirar por joyas, estatuas y coronas.

No se debe aspirar más que a la satisfacción de los deseos naturales y necesarios. Por esta senda se alcanza la única felicidad verdadera que viene de la paz interior, de la serenidad del alma. Asi se obtiene el estado que se llama afara$x i a$, en que el espíritu vive bajo el imperio de su propia libertad.

Se ve cómo el epicureísmo. poniendo por encima de todo el goce espiritual que resulta de la tranquila soberanía del alma sobre si misma, se convierte en estoicismo.

Una vez vencidos y sojuzgados los bajos instintos y apetitos materiales, ¿qué obstáculo se opone a la felicidad espiritual? Para Epicuro éste no es otro que el que proviene de los temores supersticiosos, de la religión, que mantienen el ánimo encogido y pendiente de la voluntad y de los caprichos divinos. Por esta razón nuestro filósolo atacó implacablemente las supersticiones y las religiones de su tiempo, y fué a buscar en la ciencia los conceptos básicos para asegurar la ataraxia, la independencia del alma.

Epicuro no admite, sin embargo, un determinismo absoluto, un destino, shijo del caos y de la noche,

-Sería mejor, dice, prestar fe a las fábulas relativas a los dioses que hallarse sometido a la fatalidad de los físicos. La fábula, en efecto, nos deja la esperanza de doblegar a los dioses por medio del culto y de los tributos, pero a la necesidad no se puede doblegars.

Epicuro busca una manera de interpretar la naturaleza en que no intervengan los dioses ni sea el mundo un simple juguete de la necesidad. Observa que en nosotros mismos distinguimos dos clases de movimientos, el constreñido y el espontáneo. No todos nuestros actos provienen de que seamos movidos, de que obedezcamos a un funcionamiento automático; sabemos además por experiencia lo que es moverse, lo que es la propia espontaneidad interior.

Este poder que notamos en nosotros debe existir ya en el germen de las cosas, en los átomos. No es posible representárselos como inertes y muertos, sino como llevando en sí la potencia de moverse. En los gérmenes de las cosas, fuera del movimiento producido por el choque y la pesantez, hay otro más, del cual 
nos ha llegado a nosotros mismos la potencia que nos es innata; porque sabemos que de nada no puede salir nada. De esta suerte tenemos tres clases de movimientos, que van siendo más y más profundos e íntimos: el choque, a la vez exterior y fatal; la pesantez, que ya es interior, pero parece aún fatal; y la voluntad, que marca la armonía en que culminan lo interior y lo libre.

Ya no es preciso para darse cuenta del universo recurrir a un deus ex machina, a una causa superior y sobrenatural, que sería para el hombre una potencia tiránica. El espacio y los átomos son infinitos y el tiempo se abre como algo eterno delante de ellos. ¿Qué puede haber de imposible, dice Epicuro, contando con estas tres infinitudes y como podría no bastar la fuerza espontánea de los átomos para organizar el mundo finito que se ofrece a nuestros sentidos? La infinidad misma de las combinaciones posibles de los átomos en el espacio y el tiempo infinitos hace inútil la hipótesis de una inteligencia divina, y de un plan preconcebido. El mundo puede prescindir de los dioses. Tanto la creación como el milagro son imposibles.

Epicuro afronta sin vacilar las consecuencias de sus doctrinas. Su entereza es admirable. Ya hemos visto como rechaza toda prescindencia. Insistiendo en esto dice: - El porvenir se halla abierto a la potencia espontánea, a la vida, a la voluntad. El porvenir es lo que saldrá de la indeterminación, persistente en germen aún en la determinación actual. .

La libertad, forma superior de la espontaneidad del átomo, ha de tener para el hombre un valor intrínseco supremo. La voluntad debe encontrar en la independencia el primero de los placeres y el sentimiento de la dignidad y de la personalidad. El sabio (sage) no debe contar más que consigo mismo y con lo que dependa de él. Se alzará como un luchador contra la casualidad y la fatalidad, noble lid en que, estando seguro de su libertad, puede estarlo del triunfo final. El porvenir no le inquieta. ¿Qué le importa lo que pueda suceder? $\mathrm{Si}$ es un mal lo evitará declinando, apartando libremente de él su pensamiento y su voluntad, yéndose él mismo del mundo, si fuera preciso, por medio de la muerte voluntaria.

La fortuna, la casualidad poseen tan poco imperio sobre el sabio que para él vale más ser infortunado teniendo de su parte la razón que afortunado sin ella.

¿Van a echarse sobre el sabio el sufrimiento. la enfermedad, el tormento: se le va a torturar, se le va a arrojar en el toro ardiente de Falaris? No importa. El puede permanecer siempre libre, sin inquietudes. Ilamando aún a la fortuna misma para que en forma de recuerdo de los bienes que recibiera antes llene su alma de serenidad.

Una vez más el epicureísmo se confunde por su grandeza moral con el estoicismo.

Mas para que el hombre sea enteramente libre es menester extinguir todavía en su pecho el temor de la muerte. He aquí otro de los objetivos esenciales de la doctrina de Epicuro. ¿No hay nada de temible en la vida, dice el maestro, para el que sabe que nada hay de temible en la privación de la vidas. 
La enseñanza de Epicuro constituye talvez el esfuerzo más notable que se haya hecho para librar al hombre del pavor de ultratumba, esfuerzo de temple heroico porque no lleva ningún halago de dicha futura. Cuando tres siglos más tarde el cristianismo triunfante afirmó con tanta fuerza la resurrección y supervivencia del alma, las ideas epicúreas sufrieron un eclipse. Mas en nuestros días en que, con el andar del tiempo. el cristianismo ha ido perdiendo gradualmente su poder sobre las inteligencias han renacido aquellas ideas armadas de nuevo vigor. Son pocos los que, a propósito de vida futura, se satisfacen con las afirmaciones gratuitas de cualquiera religión y el ansia de inmortalidad abate sus alas ante lo inevitable y tiende a transformarse...

¿Por qué tememos a la muerte y tratamos de evitarla?

Según Epicuro, tal temor es ingenuo. La creencia vulgar nos hace pensar que queda algo de nosotros en la muerte y es la suerte de este resto la que nos inquieta y suscita fantasmas en nuestra imaginación. Si nos persuadimos de que la muerte no tiene nada de real, de que sólo es para nosotros la disolución de toda vida, el aniquilamiento completo, ¿qué razón tendríamos para temerla? Cuando somos, la muerte no existe y cuando la muerte llega, nosotros ya no existimos. Ella no significa nada entonces ni para los vivos ni para los muertos, porque para los que son ella no es, y ella es para los que no sons.

No se puede dejar de admirar el ingenio dialéctico, tan propio de los griegos, de este razonamiento. Sin embargo, bajo su perfección formal se advierten resquicios solísticos. Se ha olvidado en él que frecuentemente no es tanto el temor al más allá lo que hace aborrecible la muerte como el pesar de dejar esta vida.

Claro que esto no quiere decir que los epicúreos no estimaran la vida. Tal afirmación sería contraria a su dogma fundamental. Epicuro protestaba de que se deseara y buscara la muerte. Pero por encima de todo se pone la afaraxia. la serenidad suprema y el maestro dió muestras de hallarse en plena posesión de ella al fin de sus días. Víctima de una dolorosa enfermedad (1) afrontó el sufrimiento con un valor que los estoicos mismos se exhortaban a imitar. Marco Aurelio recuerda en sus Pensamientos como Epicuro ha referido que jamás se quejaba ante nadie de los dolores de su cuerpo, que siempre discurría con los demás sobre su objeto habitual, la naturaleza de las cosas, y como, a pesar de sus males físicos, continuaba su vida siendo feliz y tranquila.

Guyau no se resigna a que la vida humana termine inexorablemente con la muerte y entona un himno de esperanza en el más allá algo semejante al que entonará más tarde, según veremos oportunamente. Bergson en La Evolución creadora. Himnos tan entusiastas como imprecisos e indeterminados. $\mathrm{Y}$ no podrían ser de otra manera.

-En resumen, dice Guyau, hay dos clases de temor a la muerte que Epicuro no ha distinguido: un temor pueril y cobarde en que a la imaginación corresponde el principal papel y otro intelectual y viril que se asienta sobre todo en la ra-

(1) Piedras al hígado. 
zón, y es, más que temor, horror desinteresado a la muerte. Epicuro ha sabido señalar la vaciedad del primero; nó la del segundo. Es evidente que el temor de ser castigado por una potencia exterior es pueril. Los infiernos son una concepción derivada de esta vida. Pedir una mercenaria recompensa de ultratumba es poco digna. Mas, por otra parte, se puede aspirar a no merecer, se puede desear, sin contar absolutamente con ella, una existencia que signifique un progreso respecto de la terrestre; se puede pensar que la muerte sea un paso hacia adelante, no una brusca detención en el desarrollo del ser; se puede en fin esperar no perder, como en un naufragio, todas las riquezas interiores que uno ha amasado, sino que atravesar la sombría portada llevando consigo gloriosamente el mundo de pensamientos y de querer generoso que uno ha sabido lomentar en sí mismos.

Confieso que a este clamor algo dolorido al frente de la intrusa prefiero la serenidad estoica de Epicuro; pero entendiendo, sí, que ella no significa la detención en el desarrollo del ser. Se extingue nuestra personalidad individual; más persiste la obra de proporciones indefinidas e imprevisibles en que colaboramos. obra que tiene desde ya los caracteres de una gran creación espiritual.

Las virtudes superiores para los epicúreos son el valor y la temperancia. Temperancia ante las tentaciones, valor ante las dificultades: otros secretos de única dicha que es dado alcanzar a los mortales. Se observa una vez más que Epicuro no era un burdo buscador del placer sensual.

En el afecto amoroso distinguen los epicúreos dos cosas: la pasión propiamente dicha y la necesidad fisica. Esta que es natural, debe ser satisfecha; aquella evitada. El sabio ha de huir del amor como de un mal irreparable. La canción del amor, tan cantada por los poetas, nada tiene de natural ni de racional. No pasa de ser una ilusión psicológica; es, al decir de Lucrecio, una tendencia a dotar al objeto amado de toda perfección, a divinizarlo; lo que viene a parar en una tendencia absurda.

El matrimonio no queda libre de estas admoniciones negativas. Trae consigo forzosamente mil cuidados y es mejor para el sabio no casarse ni tener hijos. Por donde se ve que en este punto los epicúreos fueron precursores de los primeros cristianos. Con el cristianismo la prevención contra el matrimonio aumentó en vez de disminuir. Las almas buscaban la soledad. Se creía que aislándose se estaba más cerca de Dios. El éxtasis reemplazó al amor.

La amistad, en cambio ocupa un lugar de honor en el sistema epicúreo. Partiendo de un interés egoísta llega Epicuro, como le ha de ocurrir a Bentham siglos más tarde, a reconocer la necesidad de la simpatía y de los afectos puros. La amistad es, como la virtud, un medio tan eficaz de felicidad. que se confunde enteramente con la felicidad misma. Amistad, virtud. felicidad no serian más que tres aspectos diversos de una sola cosa. El sabio ha de rendir, si es 
preciso, la vida por su amigo. Epıcuro era para con los hombres, según Diógenes Laercio, de una benevolencia sin igual.

Para los epicúreos no existe un derecho natural. El derecho es una creación humana derivada de las necesidades sociales, un pacto de utilidad tendiente a que no nos lesionemos recíprocamente. La justicia no significa algo que tenga valor en sí; ella sólo existe donde hay contratos mutuos. De este modo, sin sociedad no hay derecho, y este viene a cimentarse en el interés general. Análogas ideas sostendrán los utilitarios, evolucionistas y positivistas contemporáneos.

Igualmente anticipándose dos mil años al espíritu de los siglos XVIII y XIX en la proclamación de uno de sus dogmas más queridos, el epicureísmo fué la primera doctrina de la antigüedad que sostuvo la idea del progreso; pero no fué Epicuro mismo sino su discipulo Lucrecio quien hizo del progreso una acabada descripción.

Las ideas de Epicuro sobre los dioses son muy originales.

En primer lugar rechaza la idea de un dios creador. Apoyándose en la existencia del mal hace Epicuro la siguiente formidable argumentación, citada por Lactancio: .O Dios quiere suprimir el mal y no lo puede; o lo puede y no lo quiere; o ni lo quiere ni lo puede; o lo quiere y lo puede. $\mathrm{Si}$ lo quiere y no puede es impotente, lo que no le sienta bien a un Dios; si lo puede y no lo quiere, es envidioso. lo que sería aún más impropio en un Dios; si ni lo quiere ni lo puede, es a la vez envidioso e impotente, $y$, por consiguiente, no es Dios; si lo quiere y lo puede, que sería lo único digno de un verdadero Dios, ¿de dónde viene el mal entonces? ¿O por qué Dios no lo suprime?,

Después de este razonamiento cuadrilateral, fuerte y vigoroso como un haz de rayos. Epicuro desarrolla una concepción algo pueril de los dioses.

De lo dicho anteriormente no fluye para Epicuro que sea preciso caer en en el ateísmo. Lo que sí niega es la existencia de un Dios único, creador y ordenador del mundo.

Como los hombres creen en los dioses, estos deben existir. Homenaje rendido a la creencia general. Los dioses son inmortales y bellos y disfrutan de la suprema felicidad. De aquí, entre otras cosas, porque no sea dado atribuirles la creación ¿Qué cosa más contraria a la dicha que haber creado un mundo lleno de imperfecciones y vivir bajo el peso de la preocupación incesante de tener que arreglarlo, repararlo? Ah no! los dioses no existen para esta labor de mayordomos. Sólo la ignorancia humana ha podido imaginar un acto de creación del universo. Los dioses son seres semejantes a nosotros, pero de belleza perfecta, y constituídos de una materia más sutil que la nuestra, porque 
fuera de los átomos no hay nada. Viven en los espacios interplanetarios y, como los seres terrestres, tienen sexo y se alimentan, pero sin que les cueste el sustento el sudor de su frente.

Para con estos dioses los epicúreos eran piadosos, desinteresadamente piadosos. De tales divinidades no esperaban nada. Ellos sabian que los dolores y anhelos de los hombres no les inquietaban. Iban a los templos a adorarlos porque representaban un tipo perfecto de serenidad dichosa. Eran la realización del ideal que ellos soñaban para el hombre.

Epicuro desempeñó en su tiempo un rol semejante al que ha tenido Augusto Comte en el nuestro; pero talvez con más influencia que la del apóstol del positivismo. Sus doctrinas han ejercido una acción incontestable sobre el desarrollo del pensamiento humano. En las ciencias naturales, en sociología y aún en moral, Epicuro abrió las sendas del espíritu moderno. Casi todos los filósofos del siglo XVIII, y en especial los enciclopedistas, fueron epicúreos. La escuela inglesa ha levantado al frente del estoicismo restaurado por Kant un epicureísmo renovado por medio de los datos de la ciencia moderna. En las teorías de pensadores modernos como Strauss. Feuerbach y Schopenhauer se oyen resonancias del doctrinal epicúreo.

Quiso el maestro griego apartar la inteligencia de las nieblas metafísicas que se habían venido acumulando con las especulaciones a priori de casi todos los filósolos anteriores, y aún con las de Sócrates y Aristóteles.

Esta tarea de concentración del espiritu se halla expuesta a limitaciones y errores. En ellos cayó Epicuro, como debía ocurrirle también a Augusto Comte. Epicuro declaraba de antemano, por ejemplo, que no podrían jamás explicarse los fenómenos celestes y rechazaba. por inútiles e incompetentes, ciencias como las matemáticas superiores.

Pero sustituyendo un método experimental, aun grosero, a las tendencias metafisicas que dominaban desde Sócrates, sustituyó en las ciencias la estéril e infundada idea de causa final por las ideas de tiempo y de sucesión. El nuevo surco abierto fué fecundo. ¡Cuantas ideas añejas y prejuicios ha barrido el epicureísmo de los dominios de la morall Asimismo en la esfera de las religiones los epicúreos han contribuido más que en ninguna otra escuela filosófica antigua a emancipar al pensamiento humano de la creencia en lo milagroso y lo providencial. Mucho antes de la aparición del cristianismo habían atacado el credo pagano, haciendo que se fuera desmoronando como una cosa carcomida interiormente.

Ha estudiado también Guyau la moral del estoico Epicteto y es curioso que no haya visto las innegables analogias que hacen del epicureísmo sólo un estoicismo que oculta su austeridad bajo un gesto de aparente alegria. El placer de 
los epicúreos es un magro placer que se satisface con lo natural y necesario con eagua y pan de cebada. El epicúreo renuncia a la riqueza, a los honores, a la gloria y al amor y busca la dicha suprema de la vida en la afaraxia, en la soberanía de la libertad interior. Su placer queda reducido a la abstinencia. ¿Qué diferencia hay entonces con el estoicismo?. En lo esencial no son ambas escuelas más que modos distintos de exponer doctrinas semejantes en la práctica.

Es por esto raro que Guyau, que apenas critica a Epicuro, no escatime sus censuras a Epicteto.

Los estoicos no han percibido la potencia infinita de la voluntad, dice, que lejos de buscar su apartamiento de las cosas las atrae hacia ella para imprimir en ellas su acción, que, lejos de abstenerse, quiere y obra en todas las direcciones posibles; que no teme los obstáculos porque tienen la conciencia de una fuerza capaz de vencerlos! que, al darse y prodigarse no teme al desengaño porque no hay decepción capaz de abatirla y ningún don de si misma puede agotarlas.

-El bien no consiste solamente, como lo cree Epicteto, en lo que depende precisamente de nosotros: consiste en hacer depender de nosotros más y más cosas, en extender sin cesar el dominio de nuestra voluntad. En lugar de ponernos aparte de la naturaleza, es menester someterla. Asi los estoicos, no habiendo penetrado la verdadera esencia de la libertad humana, no han comprendido el verdadero papel del hombre en el mundo. Han creído que el hombre debía aceptar el mundo tal como es, inclinarse ante todo lo que sucede, no desear ni querer nada mejor. ¿No debe el hombre, al contrario, aspirar y trabajar por el progreso del mundo? Corresponde al ser superior de la naturaleza. al hombre. que las cosas no giren en un círculo eternos.

-Asimismo, el verdadero papel del hombre en la humanidad ha escapado a los estoicos. De su concepción incompleta de la voluntad humana ha derivado su incompleta concepción del amor a los demás. Aconsejando al hombre que comunique los dones de su ciencia y de su razón. pero que no entregue toda su afección, que se retenga y se limite, le han prescrito en último análisis el egoísmo. (1)

Hay en la actitud de Guyau al frente de los estoicos dos cosas. Por un lado se puede ver en ella la expresión de su noble temperamento siempre abierto a la abnegación. Por otro, es la rebelión del hombre moderno, confiado en sí mismo, movido por ensoñaciones de progreso, que lucha, mientras el antiguo de los siglos de decadencia, herido en la raiz de la esperanza, busca el bienestar en la paz de la abstinencia y se abate ante el destino.

Sin embargo, el estoicismo quedará como uno de los más imponentes y desinteresados esfuerzos para fundar la moral en las solas potencias espirituales del alma humana. Los Pensamientos de Epicteto y Marco Aurelio son monumentos de grandeza y belleza eternos.

(1) Guyau-Manuel d'Epictéte. 
Después de rechazar la moral estoica no se va a sentir satisfecho tampoco nuestro filósolo con las doctrinas inglesas contemporáneas. Aunque en verdad lo que hace Guyau es mostrarse escéptico respecto de toda moral que pretenda encerrar la vida en un marco de normas definitivas y completas.

Según él, la moral inglesa reposa sobre las tres grandes leyes físicas y psicológica de la asociación. de la selección natural y de la evolución, eque todo pensador serio no está obligado hoy día a admitir ; pero lo malo estriba en que haya pretendido formar un todo normativo de integridad acabada. ¿No tiene la moral obligatoria, se pregunta Guyau, como la metafísica, su principio en un incognoscible? ¿Es posible en el estado actual de nuestros conocimientos una moral que pretenda llevar sus reglas a toda la esfera de nuestra conducta, según deducciones rigurosamente científicas. sin mezcla de hipótesis metafisicas? La parte psicológica de la moral, o sea el análisis de los sentimientos y de los instintos puede ser tratada científicamente. Cabe decir lo mismo de la parte histórica y social en cuanto los hechos externos forman los eslabones de encadenamientos de casualidad. Pero la parte normativa no se sujeta a un tratamiento semejante. Una ciencia de la moral absolutamente completa, que abrace todo lo porvenir de la humanidad y de cada individuo, se presenta como mucho más complicada que cualquiera otra ciencia y superior a las fuerzas del espíritu humano. Lo incognoscible presenta siempre un paño de sombras en alguna proyección del porvenir, y lo hipotético es la única luz dudosa con que podemos arriesgarnos a disiparlas.

Digamos desde luego que Guyau va a oponer a la moral evolucionista, como la doctrina más bien armada para triunfar sobre ella, la de la libertad moral o de la autonomía de la voluntad. Reconozcamos también que para el caso la expresión slibertad moral, no es afortunada. Mejor es la cautonomía de la voluntad.. Según esta, nosotros no seríamos simples fenómenos intermediarios en un proceso determinista indiferente, sino que la razón y fin de nuestros actos estarán en nuestras propias entrañas espirituales, en nuestra personalidad, en nuestra voluntad de abnegación y amor.

En la moral inglesa encontramos en primer término el utilitarismo de Bentham, ensanchado y perfeccionado por Stuart Mill. En seguida a mediados del siglo pasado toma la forma del evolucionismo, preconizado por Spence.

El filósolo Reid, anterior a Bentham, habría al parecer abusado del método intuitivo. Nuestra razón, nuestro sentido moral percibiria, conforme a los cánones de este método, por intuiciones inmediatas la calidad buena o mala de las acciones. Según Reid, sería imposible la continuación de una ciencia de la moral capaz de llegar a proporciones lógicamente encadenadas. Cada juicio moral provendría de una intuición aparte, independiente, aislada. La moral pasa a ser una casuistica. 
Contra esta desarticulación de la moral quiso reaccionar Bentham, aplicando a los problemas morales el método experimental en lugar del intuitivo. El no acepta la intuición moral y no valoriza la moralidad como categoría aparte e independiente. Los hombres buscan el placer, la felicidad, la satisfacción de sus intereses. El secreto de la sabiduría consiste en orientarlos sobre cuales son los verdaderos placeres y sobre la manera de establecer la armonía entre los encontrados intereses humanos. De aqui que Bentham entrara en un estudio comparativo de los placeres y de las penas, estudio algo mercantil, hecho por medio de la aplicación del cálculo aritmético para justipreciar los goces y los dolores catalogados en tablas adecuadas. Bentham soñaba con una especie de stermómetro moral, gracias a cuyo auxilio la ciencia de las pasiones o patología mental podría medir la suma del placer provocada en cada individuo por cada objeto.

Con Stuart Mill, el método experimental cesa de atenerse a la simple comparación de los hechos, a la pura estimación de los placeres y de las penas. No observa sólo los fenómenos sino que, elevándose de lo particular a lo general, se esfuerza por inducir las leyes que los rigen. Asi, los fenómenos morales, como los psicológicos, llegan a quedar englobados dentro de la gran ley de la asociación de las ideas. En vez de limitarse a una serie de inducciones puramente empiricas, Stuart Mill reconoce que la moral, como las demás ciencias, tienden al progresar. a hacerse más y más deductiva. Sólo el principio básico será obtenido por inducción. a saber, el deseo universal de felicidad; pero una vez cimentada esta piedra angular, se irán desentrañando de ella y poniéndolas encima por medio de deducciones sucesivas todas las consecuencias que atesora. La moral concluirá por formar una cadena de demostraciones arrancadas de un solo núcleo experimental; será una ciencia inductiva en su principio y deductiva en sus aplicaciones.

Spencer va más lejos todavia. Quiere que el primer principio de que se deduzca todo el resto posea un carácter de necesidad que se comunique luego a cada una de sus consecuencias, de tal manera que lo arbitrario quede excluido del sistema entero de la moral. Para esto relaciona la ciencia de las costumbres con la ciencia del universo y el deseo de felicidad en el hombre a la ley suprema del mundo: la conservación del ser.

Gayau toma la balanza para sopesar las razones de intuicionistas y de empíricos colocados frente a frente. Dara aquellos la moral tiene que descansar sobre el sentimiento del deber. sobre el sentido moral, que sería un dato primitivo e innato. Para los segundos las normas de conducta se derivan de una necesidad, de un principio que en sí no tiene nada de moral, del instinto de conservación, de la busca de la dicha. Y llega nuestro filósofo a la conclusión de que ambos métodos sustentan concepciones metafísicas no susceptibles de prueba rigurosa. Lo difícil, talvez lo imposible, agrega, es encontrar un punto de apoyo inamovible para cualquier sistema.

Sin embargo, me parece que no corresponde a los dictados de la verdad dejar suspendidos a igual altura en el aire a los dos métodos. En las actuales generaciones humanas cabría hablar de la existencia de una intuición moral. Puede ser la obra de una herencia de necesidad social prolongada a través de millares 
de años. Pero esto no querría decir que lo ético sea un valor primitivo. El sentido de lo ético es quizás menos primitivo que el sentido de lo bello. En un principio sólo es concebible el afán de vivir, el instinto de conservación. y ese afán amarrado a la necesidad ineludible de la convivencia social ha tenido que transmularse en normas que en sus comienzos no han sido puramente éticas, sino religioso-ético-juridicas; un confuso conglomerado, de donde el tiempo ha sacado la sustancia para ir formando las religiones, las morales, los derechos. Nadie podrá negar que lo ético sea hoy un valor en sí; pero no un valor primitivo sino derivado; es una de las creaciones espirituales del hombre.

Volvamos a los fines de la moral.

En el llamado de. Buscad el placers se condensa el fin señalado por los utilitarios: pero como hay placeres de tantas clases. Bentham y Stuart Mill se han afanado por encontrar un criterio que decida cuales deben preferirse.

El primero cree haberle hallado simplemente en la cantidad medida según siete condiciones, a saber: intensidad, duración, certidumbre, proximidad, fecundidad, pureza y extensión. La unidad final propuesta como objeto a la conducta por el moralista será el máximun de placer. La moral de Bentham resulta una moral aritmética de una ingemuidad admirable. Por supuesto que Bentham ha estado muy lejos de demostrar que todos esos elementos del placer sean reducibles a cantidades. ¿Cómo comparar entre sí los diferentes placeres? Siquiera los que se deben a un solo sentido son apenas comparables. ¿De qué manera hacer entrar luego en parangón a los goces del gusto con los de la vista y el oído? iY cuanto no se enreda y complica en seguida la comparación si iniervienen los del amor y de la inteligencia!

Guyau analiza minuciosa y hábilmente los detalles del método benthamista y pone de manifiesto la absoluta imposibilidad de reducir a cantidades los placeres y las penas. ¿Cabe por ejemplo, medir con cualquiera especie de números el placer de leer un bello pensamiento filosófico o el de seguir la rigurosa demostración de un teorema? ¿Seria dado establecer entre dos placeres relaciones exactas de mera cantidad? ¿Sería capaz el moralista utilitario de expresar en cifras la admiración y el entusiasmo?

Los placeres estéticos, morales y sociales no se muestran menos rebeldes a los números. ¿Qué hacer todavía para comparar un placer estético o moral con uno material, un sabor con un afecto, un dolor con una buena acción? La virtud no se confundirá jamás con el gusto. No podeis pasar del olfato al espíritu sin franquear una distancia que parece inconmensurable.

Si las relaciones de los placeres entre sí nos colocan en situación embarazosa para apreciarlos numéricamente, más dificil es aún salir del paso si queremos comparar los placeres y los pesares. ¿De qué manera reducir. por ejemplo. a una común medida el dolor de un cólico con el placer de escuchar un poema 
- la amargura del ruibarbo con la belleza de una pieza de música? ¿Cómo expresar una pena con signos aritméticos?

Lo que Guyau afirma se halla de acuerdo con los escasos resultados obtenidos hasta hoy por la psicología experimental, pues sólo ha llegado a la medición de sensaciones y percepciones simples. Los fenómenos complejos se escapan a sus aparatos como un vaho a las redes o mallas más sutiles.

- Los benthamistas, agrega Guyau, se parecen a los pitagóricos que creían estar en lo exacto cuando decían que la justicia era un número cuadrado, que la amistad era una proporción, que el matrimonio es el número tres, que la vida animal es seis, la vida humana siete, y la divina ocho. El sistema de Bentham no pasa de ser una utopía pitagórica y. como en el caso del filósolo de Samos. los números son puras metáforas. Son apariencias de intelección.

Además, la idea de la libertad interior y la voluntad son capaces de desbaratar todo cálculo sobre el placer y el dolor. La idea de libertad puede. según Fouillée, engendrar un poder moral independiente. Si me persuado, con o sin razón, de mi libertad y de mi dignidad, el dolor, desafiado por mí, será ahogado. el placer desdeñado por mí, no será sentido. La voluntad puede hacer que depongan su rigidez las tenazas del dolor y que sea menos embriagador el aguijón del placer.

Fracasado en el establecimiento de una saritmética moral, , los benthamistas han ido a parar a una cestadística moral, por medio de la cual se establecerían términos medios en el valor de los objetos o actos placenteros. Se busca la formación de cuadros de valores para una posible mayoría.

Mas las excepciones no faltan y las reglas obtenidas por la estadística moral no pueden ofrecernos nada cierto: son un simple cálculo de probabilidades.

Desde el punto de vista de la busca exclusiva del placer, dice más o menos Guyau, lo único positivo viene a ser el goce inmediato e intenso. Pobre goce, por lo general el menos durable, y que es a menudo nada más que la floración del vicio. La moral benthamista, señalando como fin el más gran placer. establece y acepta por eso mismo todas las contradicciones y excepciones que la idea del placer trae consigo; ella no sólo tolera en ciertos casos la embriaguez: la ordena; ella no sólo tolera tal o cual vicio: desde el momento que en un caso dado es preferible para el individuo, lo ordena. Acordemos, pues, con Bentham, que obra bien aquel que encuentra el mayor placer en el embrutecimiento. Debemos tener el valor de alabarlo, ya que carecemos de la facultad de condenarlo. La Moral de Bentham es una casuistica; placer es para cada uno lo que él siente como tal.

El cálculo de los placeres no ha resultado, como lo prometía Bentham, ni exacto, ni cierto ni de un alcance universal.

Stuart Mill ha tratado de eludir las dificultades del utilitarismo, tratando de medir el placer por su calidad, independiente de la cantidad y del sentimiento moral; pero no se libra de esta suerte de la implacable crítica de Guyau. sDesde el punto de vista de la experiencia, dice este, no es posible discernir en ningún placer la existencia de una calidad, independiente a la vez de la cantidad admi- 
tida por unos y de la moralidad admitida por otros. Desde el punto de vista de la razón no se puede explicar esta cantidad. En lin, en la aplicación práctica no sería dado ni discernirla ni preferirla. El criterio de Stuart Mill no es, pues, ni evidente, ni demostrable ni aplicable.

Expongamos las conclusiones a que llega Guyau y como define su propia actitud al frente del utilitarismo.

A nuestro filósofo le parece dificil fundar en simples hechos, con la ayuda de inducciones puramente cientificas y sin hipótesis metafísicas, una moral en la acepción estricta en que se toma este término ordinariamente. La llamada emoral inductiva, no ha logrado. como se imagina, encontrar un criterio seguro, ni señalar una obligación ni una sanción.

La moral utilitaria ha tenido razón al oponer desde su origen las conclusiones de la ciencia positiva a las fantasmagorías de la moral mística. Esta, sea que invoque una pretendida revelación, sea que se apoye en la intuición, coloca el bien fuera de nosolros, le dá una forma determinada y nos impone, amenudo por la fuerza, una conducta invariable. Hace la moral mística del bien un fetiche y el utilitarismo ha andado acertado en derribar ese idolo de un bien que no sería ni la bondad interior de un ser verdaderamente moral ni el placer de un ser sensible.

Pero los utilitarios no han sabido comprender los sistemas adversos al suyo de una manera completa. Cuando se habla de smoralidad. Bentham y Stuart Mill creen que siempre se entiende este término en un sentido transcendente metafísico. numenal, es decir, como algo para ellos enteramente verbal, sin connotación alguna. Pero no es así. Tal reproche puede valer en contra de Kant y de los intuicionistas y místicos aun numerosos en Inglaterra: mas no todos los impugnadores de la moral utilitaria son partidarios del intuicionismo. Existe, pues. una doctrina que, sin ser intuicionista ni mística, disputa al utilitarismo el campo de la moral.

Según nosotros, dice Guyau, si hay una moral capaz de seducir a los espíritus amantes del ideal, si existe una que forme un sistema bien trabado. un todo homogéneo, es la que ha tratado de fundarse sobre la idea de sla libertad moral que encuentra en sí misma su fuerza y su fins: en una palabra es la moral que entrevieron demasiado vagamente Zenón y Epicteto y de la cual puso Kant los primeros fundamentos. Pero Kant, este pensador a la vez tan moderno y tan escolástico. mezcló en su sistema ideas metafísicas muy discutibles. La filosofía contemporánea ha tomado en sus manos de nuevo este sistema, e interpretándolo en sus sentidos más profundos, se ha esforzado a la vez en simplificarlo y enmendarlo. Esta moral de la voluntad autónoma y automotriz ha ganado terreno en los últimos tiempos.

Guyau tiene arranques líricos en defensa de la libertad. «cuyo germen llevamos en nosotros, que debemos respetar en todo y en todas partes, en las 
menores acciones, en la vida y en la muertes. Los partidarios de la libertad, sea real, ideal o virtual, llevan en ella una fuerza incontestable; se presentan además como nuestros propios defensores y los protectores de nuestro yo contra la invasión de la naturaleza y de su determinismo impersonal,

Guyau continúa defendiendo la libertad con vehemencia elocuente y lírica.

Siguiendo a Fouillée, para ir luego más lejos que él, saca el problema de la libertad del terreno de la casualidad. No piensa en defender una libertad que se sustraiga a determinaciones. Va a poner la libertad como ideal y traslada el problema al plano de la finalidad. La naturaleza propia del hombre radicaría nó en sus bajos deseos sino en sus aspiraciones superiores. En el fondo del corazón humano habría un núcleo de nobles facultades en potencia. La busca de la libertad no sería más que la trayectoria ideal que lanzan esas facultades para realizarse. La moral de la libertad, de la autonomía de la voluntad señala como ideal el perfeccionamiento constante del ser. La moralidad sustraída al realismo férre a térre de los utilitarios, pasa a ser una ansia de perfección. Guyau va tras la libertad en parte en el sentido en que la entendian los estudios, como liberación del alma de sus tendencias inferiores, pero los sobrepasa con mucho en que no es un resignado sino un fervoroso creyente en el mejoramiento humano, en que no cierra su pecho a todas las pasiones sino que vive abrasado en grandes amores, en que no busca la paz, rayana en la indiferencia propia del estoicismo, sino que se halla presto a todos los nobles combates a que lo llama su condición de caballero del ideal.

Creemos que Guyau ha estado en lo cierto al salvar del determinismo absoluto una especie de pequeño recinto interior sagrado, una partícula de espontaneidad en la voluntad. No somos partidarios del libre albedrío, de la libertad indeterminada que defienden algunos metalísicos para salvar el orden teológico del mundo. A la inversa, tampoco creemos que se pueda afirmar que somos absolutamente determinados. Hay un pequeño seno en el fondo de nuestro ser donde parecen refractarse las fuerzas exteriores a nuestra psíquis. Existe así una sutil y tenue cuestión de fronteras entre la libertad y el determinismo. Cuantas veces nos sentimos libres tan sólo en realidad porque somos responsables. Cuantas veces nos sentimos libres únicamente porque hemos asimilado hechos, propios motivos que han venido obrando de fuera durante largo tiempo sobre nosotros: Cuantas veces la conciencia de nuestra libertad no es más que la contemplación en nuestro campo visual interior de los diferentes caminos que se nos ofrecen a seguir y de la vida que tenemos de nuestra personalidad. Esta a su vez se ha ido formando por nuestras circunstancias prenatales, nuestra educación y por hechos propios y ajenos que han ido dejando su peso muerto en los años que hemos vivido. Nosotros llamamos obrar con libertad proceder conforme al dictado que interpreta mejor nuestra personalidad completa, y así asumimos la responsabilidad de lo que hacemos. A veces brota en el individuo alguna idea. alguna actitud nueva que podemos señalar como creación del espiritu. Es el caso más indicado en que parece que nos sustraemos a un determinismo riguroso. Creamos en la fuerza espiritual creadora pero la libertad sin determinaciones no 
se puede defender con simples declamaciones, por más elocuentes y generosas que sean. Creamos en la fuerza psíquica creadora de ideas nuevas y de valores espirituales. La libertad asi entendida dentro de estas premisas viene a ser expresión de la personalidad; es espontaneidad, y facultad de creación.

Menos claro que antes encontramos a Guyau en las críticas que hace a la teoría de la evolución de la moral.

En lugar de un ideal inmutable la escuela inglesa nos ha mostrado la sin cesar cambiante realidad. La moralidad no tendria pues, nada de fijo. Lo que es moral aquí es inmoral en otra parte. Un meridiano decide la verdad. como decía Pascal hablando de los escépticos; y lo justo cambia de calidad al cambiar de clima porque lo justo queda reducido por completo a un juego de intereses, que son de por sí muy variables.

La teoría de la variación y de la evolución en moral, agrega Guyau, se halla ligada en su forma moderna a la gran teoria de la variación y de la evolución en las especies animadas. Aquí busca su primer argumento. La lucha por la vida, que no es más que la lucha de intereses, explica todo el mundo animal; y como el mundo humano se deriva del mundo animal esta ley debe explicar también todo en el mundo humano y la pretendida moralidad queda convertida en la reducción progresiva de los intereses a la armonia, por medio del triunfo continuo de las formas superiores de interés sobre las inferiores.

Se vé que Guyau trata de afirmar que la falta de un ideal moral en los comienzos de la vida humana se ha obtenido de una manera deductiva, en virtud de la mera interpretación del principio de la lucha por la vida. Pero esto no es exacto. Ha sido gracias a la observación directa de los hombres primitivos como se ha llegado a semejante conclusión.

Más adelante Guyau condena la aplicación de método inductivo. genético, antropológico a los problemas morales y censura a los idealistas que, según él. se dejan extraviar por esta manera de encarar la cuestión. Si los espiritualistas; dice, supiesen creer en su bien moral, se guardarian de ligarlo a cosas de que se puede dudar; antes de inquirir los orígenes del hombre depurarian la idea que uno debe formarse de la moralidad humana y la separarian de todo lo que es extraño a fin de arrancarla del dominio de la historia natural: lo que es inferior a la moralidad no puede alcanzarla (atteindre). Dicho con perdón de toda la estimación que me merece Guyau, eso no pasa de ser una afirmación grandilocuente, pero verbal y hueca. En todos los órdenes de la vida se ve que lo inferior alcanza, motiva e influye sobre lo superior.

Luego continúa:

- La verdadera cuestión no está en saber cómo ha sido producida la especie humana. La cosa que importa conocer es lo que es el hombre, y, sobretodo. lo que debe sers. 
¿Y para saber lo que es el hombre es un asunto baladi despreciable, averiguar el origen y manera de formación de la especie humana?

Creo al contrario, que para tener su concepto integral de la naturaleza humana es indispensable partir de la génesis de nuestra estirpe. Me admira que un espiritu tan comprensivo como el de Guyau haya dejado de ver cuanta luz puede derramar sobre nuestros problemas actuales todo lo relacionado con los comienzos de la vida humana.

Para Guyau la variedad de los usos morales no implica la negociación de una moralidad ingénita en el hombre. Proceder así es confundir las normas y los sentimientos morales, que son mudables, con la voluntad moral, la voluntad del bien, que existe siempre. Que unos pueblos maten y hasta se coman a sus padres, que otros asesinen a sus hijos, que estos honren el robo y aquellos prostituyan a sus vírgenes no arguye nada, según Guyau, en contra de la existencia de una moralidad intima. Esas gentes han tenido la voluntad de proceder bien: se han equivocado, pero han buscado el bien y han sido morales.

A este razonamiento cabría observar que entendidos asi la moralidad, el bien. quedan reducidos a la buena intención, a un término tan abstracto que carece de toda otra comprensión. Por otra parte, como esa buena intención no pasa de buscar la aplicación en cada caso de lo que más convenga a la vida del individuo o del grupo es en realidad una manifestación del instinto de conservación. que nunca falta en los organismos vivos. Y siendo asi carece de un carácter específico que la diferencie y constituya en verdadera moralidad.

Al preconizar la tesis de una moralidad innata en el hombre se cuida bien Guyau de entenderla en una forma invariable. Al contrario; cree que ha sido un error fundamental de los espiritualistas quedarse en las viejas teorias de la moral inmutable. A medida que vaya progresando la humanidad las costumbres se pondrán en armonía unas con otras, las ideas morales se irán reduciendo a la unidad. De aqui que en estas ideas mismas se efectúe una evolución que, a los ojos de los idealistas. muestra la presencia y acción incesantes de un principio de moralidad. Esta evolución en vez de ser e! simple producto de las luerzas fisicas y de las relaciones económicas entre los intereses, es el efecto y la manifestación de la voluntad humana.

Pero Guyau no se contenta con afirmar la moralidad innata en el hombre. Va mucho más lejos. Dejándose llevar por un panteísmo delirante la pone en los animales en la naturaleza inanimada entera. ¿Por qué no ligar, dice, el espíritu humano a este espíritu aún ignorante de sí mismo que se agita interiormente en la naturaleza?. ¿por qué cerrar la naturaleza a toda voluntad de lo mejor, a toda moralidad?. ¿por qué prohibir a los otros seres, por infimos que sean, que tengan alguna vislumbre del ideal? Si ellos llevan ya en si a la gran humanidad, de que son los antepasados, deben tener también en algún grado sus aspiraciones y sus deseos?.

¿Cabe atribuir alguna objetividad a este arranque lírico? No es posible dejar de mirarlo con una sonrisa de simpatia como hermosa vaguedad de un noble soñador. Pero nada más. Es posible imaginarse que todo átomo de la naturaleza 
sea el nido donde duerme una fuerza espiritual en potencia, que el seno de la piedra tenga un alma: pero no es dado concebir esas energias ya especificadas en forma de moralidad o de aspiraciones al ideal.

Guyau se complace en mostrar las transformaciones que se han operado en los utilitarios, que no pudiendo moverse con facilidad en todas las esferas de la vida dentro de los dictados del puro interés y del egoísmo han debido saltar sus propias vallas y preconizar el desinterés y el altruísmo.

En esta encrucijada los toma Guyau para acusarlos de inconsecuentes.

.Todo es interés, ha dicho Epicuro, para agregar luego que en -ciertos casos es menester saber morir por sus amigos. El desinterés, según los epicúreos romanos, no puede ser momentáneo: entre verdaderos amigos la abnegación es perpetua, no hay interrupción ni excepción; amarse es salir del interés para no volver a caer en él.

¿Todo es interés,, repiten Hobbes, La Rochefoucauld, Helvetius: pero este último no deja de sostener que persigue por su cuenta la dicha de la humanidad. La dicha de la humanidad antes que la nuestra, se complacen en repetir D Alembert, d'Holbach, Saint-Lambert; y de nuevo reaparece en la doctrina del interés la idea del desinterés. En vano, dice Guyau, la inteligencia abstracta trata de excluir de sus sistemas el ideal moral: este rompe la trama lógica del razonamiento y por sí mismo se coloca en medio del sistema bamboleante.

Bentham y sus sucesores han hecho la tentativa atrevida de unir o, más bien, yuxtaponer las dos ideas contrarias de interés y desinter és y de hacer salir al altruismo del egoísmo. De aquí dos tendencias que se han contrabalanceado y hecho equilibrio en el sistema utilitario. El utilitarismo de Stuart Mill, que valoriza el placer por la calidad y no por la cantidad, parece acercarse más que cualquiera otro al idealismo. Al parecer son más consecuentes los utilitarios que rechazan la distinción de Stuart Mill entre la calidad y la cantidad y adoptan como criterio la mayor suma de placeres. Como principal representante de esta tendencia se puede señalar a Sidgwick. Pero son consecuentes sólo en apariencias, agrega Guyau, porque deberían en verdad renunciar a fundar una moral y no lo hacen. Al revés: persiguen tal objetivo como su más cara ambición y Sidgwick habla de deber. de obligación, de moralidad, olvidando que de los meros hechos externos. de un egoísmo primitivo. de la busca inicial del placer no se puede inferir ningún sentimiento de obligación si la voluntad no lo lleva como cosa propia.

Antes de hacer notar las observaciones a que esta critica de Guyau puede prestarse, apuntemos otras de sus impugnaciones que, por lo demás, se encuentran en consonancia con la anterior.

Guyau es muy claro en la expresión de sus propias ideas, entre las que resuenan continuamente como un leitmotiv cordial, la fe en la libertad y en el amor; pero resulta a veces oscuro y confuso en la crítica que hace a las doctrinas contrarias. Así se ve en su análisis de la posibilidad del amor a los demás hom- 
bres dentro de la teoria utilitaria. Principia por rechazar Guyau todo avenimiento con Stuart Mill y Spencer para concluir de acuerdo con La Rochefoucauld, precursor en cierto sentido de los utilitarios contemporáneos, - en que pueda nacer el amor como vástago tímido de un sentimiento que en un principio no fuera otra cosa que un interés disimulado hipócritamente.

Ya sabemos que Bentham había llegado lógicamente a condenar el desinterés. Para él, los que en moral hicieran de la abnegación una virtud, se parecerian a los que en economía política hicieran del derroche un mérito. Pero Stuart Mill no se ha conformado con estas consecuencias y ha sostenido que por el hábito. la educación y la asociación de ideas es posible hacer del altruísmo una segunda naturaleza y poner en el corazón de los hombres un invencible deseo de dar. El resultado sería para la humanidad un aumento en los dones que recibiría. Asimismo dice Spencer que en la sociedad futura las esferas de actividad se harán equilibrio tan perfectamente que cada cual obrará con toda espontaneidad en el sentido del bien de los demás como si fuera el suyo propio.

Mas Guyau no acepta estas plácidas perpectivas. Les encuentra base deleznable. «EEn la doctrina del interés, dice, no se reduce el amor de la humanidad a una mentira mutua? Yo me siento a mi mismo creyendo que le amo cuando en realidad no hago otra cosa que desear algo; le miento a Ud. al decirselo; usted me miente a mi al decirme la misma cosa y yo me engaño al creerlo. Para escapar a esta mentira Helvetius suprimia simplemente el amor de los demás. ¿No era más consecuente que ciertos altruistas contemporáneos?,

Guyau no acepta tampoco ningún amor que provenga de la honda fuente del instinto. Todo instinto, dice, al hacerse consciente tiende a destruirse: la simpatía puramente instintiva se suprimirá pues al conocerse a sí misma. Esto es un error. El amor de madre y de padre y el amor sexual propiamente dicho arrancan de profundas raices instintivas que no restan a esos amores ni mérito ni importancia. Que sean espléndida luz y calor de la conciencia no quita que hayan partido de las oscuras entrañas del ser y continúen ligados a ellas. ¿Podemos negar por otra parte que la simpatía que solemos sentir por personas de uno $u$ otro sexo no tenga frecuentemente un arranque instintivo?

Pero Gayau no da valor más que al amor que brota de un movimiento libre y espontáneo de la voluntad. La necesidad exterior de la naturaleza puede aproximar nuestras esferas de acción. dice: puede impulsarme hacia usted, puede impulsarlo a usted hacia uno y estrecharnos en un común abrazo. La necesidad interior que los utilitarios llaman simpatía o altruísmo puede hacer aún más: gracias a ella nuestros mecanismos entran en equilibrio y armonía. ¿Pero es esta la ideal fraternidad de la benevolencia? Nó, porque ni el uno ni el otro hemos querido lo que hacemos ni nos hemos querido. ¿Hemos dado un solo paso que no pueda reducirse a las leyes del instinto o del interés? ¿Por qué entonces íbamos a sentir uno respecto del otro esa gratitud que parece implicar el amor?.

Más adelante, reafirmando su $f e$, aunque reconociendo que anda a tientas en el terreno de lo hipotético, continúa: Entramos aquí en esa esfera de lo incognoscible que admite Spencer y donde las diversas hipótesis no pueden ni demos- 
trarse ni verificarse donde, por lo menos, hay algunas que son más bellas que otras; algunas que parecen dar cuenta más bien de todos los impulsos que sentimos o creemos sentir en nosotros: sea espejismo o verdad, esas nos atraen por obra de una seducción invencible. Creemos en nuestra libertad real o virtual, en nuestro desinterés, tenemos fe en nuestro ser moral, fe en nosotros. Todas estas creencias se hallan seguramente mezcladas de ilusiones, de confusiones, de falsedades. Sin embargo, ¿no hay nada en el fondo, no podemos sacar de nuestra conciencia, que nos engaña tan a menudo, algo como un residuo de verdad? No se trala de salvarse en el número de Kant; sería menester encontrar una tendencia inmanente al ser mismo. ¿No sería esta tendencia fundamental, como ya lo hemos dicho. la tendencia a la expansión de sí mismo. a la liberación de toda inclinación inferior $y$, de esta suerte, a la unión con los demás, a la simpatía, al amor?

No obstante estas declaraciones tan categóricas vuelve en parte sobre sus pasos Guyau antes de terminar el párrafo y, apoyándose en las máximas de La Rochefoucauld, precursor ilustre del utilitarismo, tienta una conciliación con las doctrinas de que tanto abomina. Aún encuentra muy laudable la hipocresía, el interés que disimula para conseguir sus fines. Lo considera por lo menos un buen principio de evolución superior.

Sin esta conciliación que se va a tentar encontrariamos más desconsoladora la doctrina de Guyau que la de los utilitarios. Estos dicen: los hombres son primitivamente egoístas e interesados y no buscan más que el placer; pero de esta losca arcilla primitiva se puede sacar por medio de la educación y la evolución de los sentimientos, el desinterés, el altruísmo, el amor a la humanidad.

Guyau ha replicado: si no se encuentra en el alma un núcleo primordial, ingénito de esos sentimientos no se podrá obtener nada mejor; no hay alquimia educativa, moral o social que pueda transformar el interés en desinterés. el egoísmo en altruísmo.

Ahora, como es lo más probable, que los utilitarios tengan razón en lo que afirman sobre el fondo de la naturaleza humana y la génesis de los sentimientos. no habría dentro de las doctrinas de Guyau esperanzas de perfección para la humanidad.

Pero, en verdad. Guyau concluye por aceptar la transformación psíquica que con tanta energía rechazara en un principio.

Las Máximas de La Rochefoulcauld dice nuestro filósolo aproximadamente. constituyen una buena imagen de lo que han sido los hombres en el pasado. menos exactas al pintar como son en el presente y que no corresponderá talvez a lo que han de ser en el porvenir. Son verdaderas esas máximas, pero esperemos que los vayan siendo cada día menos. Sin duda un instinto vivaz, tendencias inferiores nos arrastran hacia abajo cuando quisiéramos ir hacia arriba. Mas nosotros tratamos de ocultar y velar estos instintos de la naturaleza animal. La Rochefoulcauld reconoció muy bien este hecho y lo llama hipocrecia. Es como una primera metamórfosis del interés. Y Guyau agrega complacido: $S \mathrm{Si}$ el interés tiene vergüenza es quizás porque se encuentra en presencia de algo superior. es porque se ve al frente del ideal concebido por nuestro pensamiento; el animal 
tiende entonces a huir delante del hombre; se puede decir en este sentido que la hipocrecia es un principio de virtud y de respeto a los demás. IEl buen Guyaul a que extremos lo lleva su placidez de espíritu!

Se vé, continúa, que la doctrina de La Rochefoulcauld y de los utilitarios puede ser en parte aceptada por todo filósolo a condición sólo de ser completada. Ella expresaría uno de los momentos y de los factores de la evolución psicológica... Se podria mostrar el gérmen de la voluntad desinteresada en el fondo mismo de la voluntad egoista. El interés no sería otra cosa que el primer grado de una voluntad que, por su naturaleza misma y cuando se siente libre de sus amarras primitivas, se abre a los demás y sólo quiere amars.

Es la conclusión a que han llegado Stuart Mill y Spencer. Guyau ha venido a coincidir con ellos después de muchos rodeos y de criticarlos implacablemente. El respeto por La Rocheloulcauld lo hizo encontrar esta conciliación. 